Збірник наукових праць. Серія: Галузеве машинобудування, будівництво

Academic journal. Series: Industrial Machine Building, Civil Engineering

http://journals.pntu.edu.ua/znp

https://doi.org/10.26906/znp.2018.51.1312

UDC 629.3.027.421.1

\title{
The definition of the direction of forces arising during the interworking of a car's steer wheel with chassis dynamometer
}

\author{
Vasyliev Oleksiy $^{1 *}$, Rohozin Ivan $^{2}$, Shapoval Mykola $^{3}$, Orysenko Oleksandr ${ }^{4}$ \\ ${ }^{1}$ Poltava National Technical Yuri Kondratyuk University https://orcid.org/0000-0002-9914-5482 \\ ${ }^{2}$ Poltava National Technical Yuri Kondratyuk University https://orcid.org/0000-0002-9052-4806 \\ ${ }^{3}$ Poltava National Technical Yuri Kondratyuk University https://orcid.org/0000-0002-6943-7687 \\ ${ }^{4}$ Poltava National Technical Yuri Kondratyuk University https://orcid.org/0000-0003-3103-0096 \\ *Corresponding author: a.s.vasiliev.76@gmail.com
}

\begin{abstract}
The article gives the theoretical substantiation of the forces determination that arise during the steerable vehicle wheel with chassis dynamometer interaction taking into account the wheels angles setting in relation to the longitudinal, vertical and transverse vehicle axes. The transition from mobile to fixed coordinate system using Euler angles is considered. The transitions comparison from the stationary coordinate system to the moving one in the system an aircraft axes and ship axes. It made it possible to move to the fixed coordinate system for a steerable vehicle wheel. A table of transition between moving and stationary reference systems has been made. The table provides an opportunity to determine the projections of forces that arise when the steerable vehicle wheel is interacting with the bearing surface when the angles of its installation are relative to the frame, are changed.
\end{abstract}

Keywords: steerable wheel, vehicle, chassis dynamometer, Euler's angle

\section{Визначення напряму сил, що виникають при взасмодії керованого автомобільного колеса з біговими барабанами}

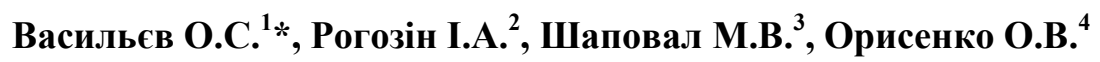 \\ 1, 2, 3,4 Полтавський національний технічний університет імені Юрія Кондратюка \\ *Адреса для листування: a.s.vasiliev.76@gmail.com
}

\begin{abstract}
Проаналізовано способи перевірки кутів установлення коліс на автомобілі та виявлено недоліки способу регулювання у статичному стані величини кутів, які є однаковими для всіх автомобілів певної моделі й не враховують індивідуальні відхилення в рульовому керуванні автомобіля. Розглянуто спосіб, який дозволяє здійснювати перевірку та регулювання кутів установлення керованих коліс при рухові автомобіля й імітації такого руху за допомогою бігових барабанів. Наведено теоретичне обгрунтування визначення сил, що виникають при взаємодії керованих коліс 3 біговими барабанами з урахуванням кутів установлення коліс стосовно поздовжньої, вертикальної та поперечної осей автомобіля. Розглянуто перехід від рухомої системи координат до нерухомої за допомогою кутів Ейлера. Виконано порівняння переходів від нерухомої системи координат до рухомої в системі осей літака й корабельних осей, що дало можливість перейти до нерухомої системи координат для керованого колеса автомобіля. Складено таблицю переходу між рухомою та нерухомою системами відліку, яка дає можливість визначати проекції сил, що виникають при взаємодії керованого колеса автомобіля з опорною поверхнею при зміні кутів його встановлення відносно остова.
\end{abstract}

Ключові слова: кероване колесо, автомобіль, бігові барабани, кути Ейлера. 
Introduction. The operation practice and scientific research show that the correct installation steerable vehicle wheels depends to a large extent on its handling, course stability, fuel consumption and tire wear $[1-3]$. Due to the tires deformation by motion, steerable wheels of a vehicle are installed at certain angles to the longitudinal, vertical and transverse car axes (longitudinal inclination angles and dislocation) [4 6]. These angles are assigned by the manufacturer for each individual car model and must be maintained within the specified limits throughout the service life.

Existing inspection methods include the wheels installation in a static state with angular angles, which is the same for all vehicles of this model [7, 8]. However, in each case there is a deviation from the norm. This is especially noticeable on cars that were in operation, in which there are kingpin strikes, bushings, joints steering rods, front axle beams deformation, subsidence front springs.

Typically, these deviations are compensated by the rather wide allowable limit in adjusting the wheels setting angles. In this case the optimal values are not stored, of course. In addition, when driving a car, the gaps in the steering control are selected, which leads to the change in the wheels initial position. In these cases, the recommended wheel angle setting cannot be the same for all vehicles of this model.

Actual scientific researches and issues analysis. Methods are also known which enable to check and adjust the steerable wheel of a vehicle angles when the car is driving [8] and simulating this motion by chassis dynamometer [9].

When designing chassis dynamometer stands, it is necessary to determine the forces acting on the drum from the wheel. In works $[9,10]$ the determination of forces is carried out taking into account only the ascent angle. Given that steerable wheels are installed at the same time at three angles, this method of determining forces is inaccurate [11].

Selection of previously unsettled parts of the general problem. Given that the steerable wheels of a vehicle are installed at certain angles relative to the car frame, there is a need to create a mathematical establish. It will allow to determine the forces projections that arise when the wheel is interacting with the support surface while taking into account the three steering wheel angles set $[12,13]$.

Setting objectives. The article purpose is the theoretical justification for determining the forces projections that arise when the steering wheel is interacting with a chassis dynamometer, taking into account the wheel angles mounting relative to the vehicle frame.

The main material and the results. Since the steerable wheel of a vehicle is set at certain angles to the longitudinal, transverse and vertical car axes, then to determine the projections of the forces applied to the wheel, it is necessary to make a transition from the moving coordinate system, which is tightly connected to the steering wheel and can change its position depending on changes in the wheel mounting angles and a fixed coordinate system that is rigidly tied to the support surface. This transition is carried out through a series of successive a moving coordinate system turns around the axes of a fixed system and their new positions.

There are several ways to move from a fixed to a moving coordinate system [14]. Often in such cases, the transition is carried out using the Euler's angles (Fig. 1).

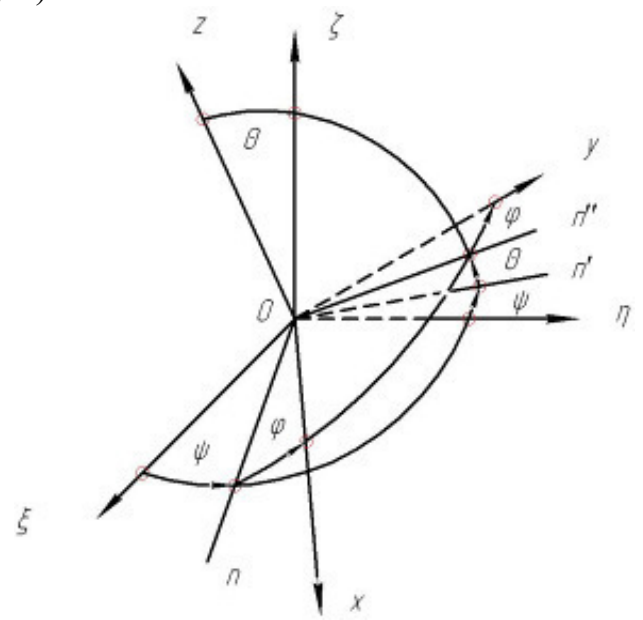

Figure 1 - The transition from a mobile to a fixed coordinate system using the Euler's angles

If, when moving from a moving coordinate system to a fixed one and taking advantage of the Euler's angles, one can notice that at small angles for the installation of driven wheels, there are small deviations axes coordinate systems moving from its original position. At the same time, the nutation angle $\Theta$ and the sum of precession angles $\psi$ and the proper rotation $\varphi$ remain small, although the angles $\psi$ and $\varphi$ themselves acquire arbitrary values within $2 \pi$. I.e. $\cos \Theta \approx 1$; $\cos (\psi-\varphi) \approx 1$.

In this case, the choice for the transition of Euler's angles is inconvenient, since using large angular values in determining the moving axes slight variations from the initial position is inconvenient due to the complexities that arise during mathematical transformations.

In some cases it is more convenient to use other orientation angles of the mobile reference system [14]. Thus, in the aircraft dynamics (Fig. 2), the $O x$ axis directed along the axis of the aircraft from the tail to the pilot cabin, the $O y$ axis - in the plane of symmetry of the aircraft, and the $\mathrm{Oz}$ axis is perpendicular to this axis (by wingspan) to the right of the pilot.

The transition from a stationary coordinate system to a moving one in the aircraft axes system is carried out by means of three turns: the first around the axis $O \eta$ on the angle $\psi$, the second - around the new position of the axis $O \zeta$ (line $O n$ ) on the angle $\Theta$ and the third - around the new position of the axis $O \xi$ (axis $O x$ ) at the angle $\varphi$. The angles of orientation are: $\psi-$ the angle of rotation, $\Theta-$ is the pitch angle and $\varphi-$ is the angle of the roll. 


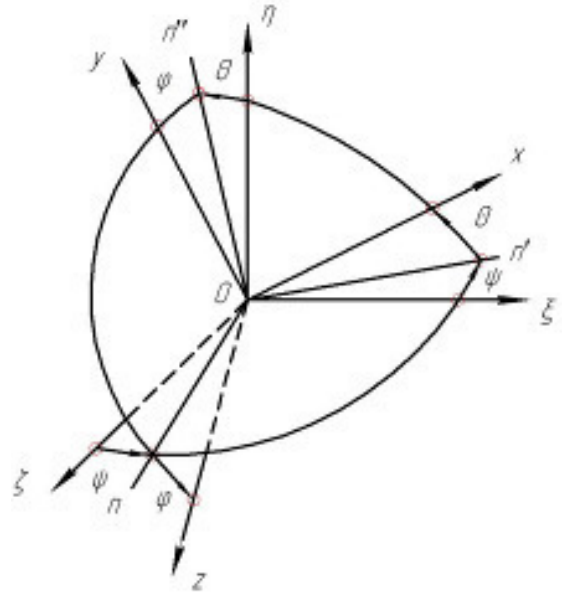

Figure 2 - The transition from mobile to fixed coordinate system of the aircraft system

Ship axles differ from the aircraft axes only by the designation. At the Krylov suggestion [14], the $O x$ axis is directed from the stern to the nose, the $O y$ axis is to the left side, and $\mathrm{Oz}$ is in the diametric plane of the ship (Fig. 3). Now the angle $\psi$ defines the divergent, the angle $\Theta$ - the roll, the angle $\varphi$ - the rigging of the ship. The transition from a stationary coordinate system to a moving axle in the ship system is carried out using three turns: the first around the axis $O \eta$ at the angle $\psi$, and the second one around the new position of the $O \xi$ (line $O n$ ) on the angle $\Theta$ and the third around the new position of the axis $O \zeta(O z$ axis $)$ at the angle $\varphi$.

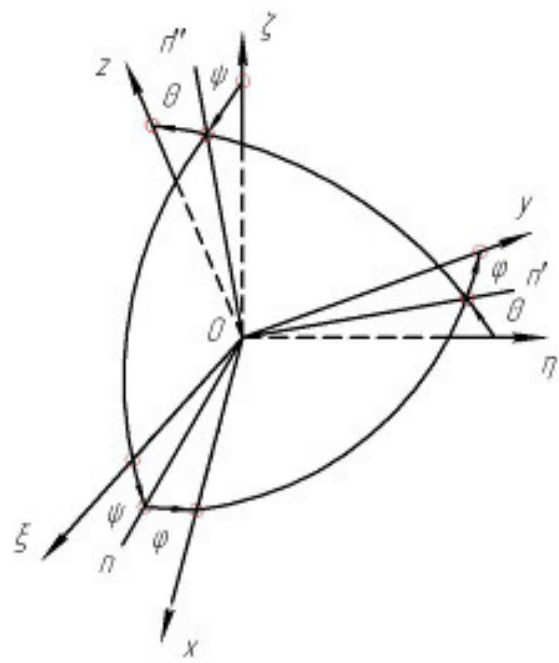

Figure 3 - The transition from mobile to fixed coordinate system of the ship system
To move from mobile to fixed coordinate system for steerable wheel of a vehicle we will use a moving coordinate system similar to the ship. The $O x$ axis is directed along the longitudinal vehicle axis, the $O y$ axis in the direction perpendicular to the vehicle axis, and the axis $O z$ vertically upwards.

Start the countdown to match the axis of rotation of the wheel. In the transition to a moving coordinate system (Fig. 4) let us consistently make another turn: the first axis $O y$ at an angle $\alpha$, the second - around the new position of the axis $O x$ (line $n$ ) at an angle $\beta$ and the third - around the new position of the axis $\mathrm{Oz}$ (axis $O \zeta$ ) on the angle $\gamma$. As an orientation angles there appear: $\beta-\mathrm{a}$ the angle of inclination of the longitudinal rotation axis (pivot), $\beta$ - the angle of the wheels collapse and $\gamma$ - angle of ascent of wheels. Thus the axis $O y$ passes into the axis $O \eta$, the axis $O x$ - in the axis $O$, and the axis $O z-$ in the axis $O \xi$.

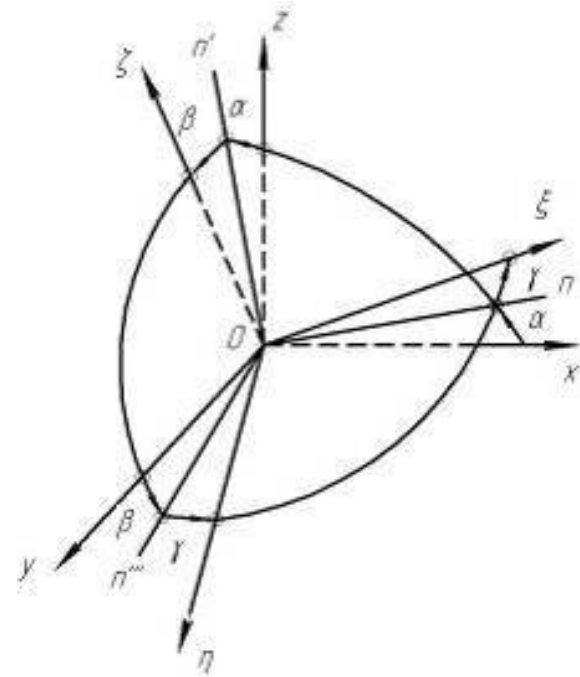

Figure 4 - The transition from mobile to fixed coordinate system for the steerable wheel of a vehicle

With such a sequence of turns, the transition from a moving coordinate system to a motionless one can be represented as Table 1.

Table 1 - Transition from moving to fixed coordinate system

\begin{tabular}{|l|l|l|l|}
\hline \multicolumn{1}{|c|}{ Symbol } & \multicolumn{1}{|c|}{$\mathrm{X}$} & \multicolumn{1}{|c|}{$\mathrm{Y}$} & \multicolumn{1}{c|}{$\mathrm{Z}$} \\
\hline$\xi$ & $\cos \gamma \cos \alpha-\sin \gamma \sin \beta \sin \alpha$ & $-\sin \gamma \cos \beta$ & $\sin \gamma \sin \beta \sin \alpha+\cos \gamma \cos \alpha$ \\
\hline$\eta$ & $\sin \gamma \cos \alpha-\cos \gamma \sin \beta \sin \alpha$ & $\cos \gamma \cos \beta$ & $\sin \gamma \sin \alpha-\cos \gamma \sin \beta \cos \alpha$ \\
\hline$\xi$ & $-\cos \beta \sin \alpha$ & $\sin \beta$ & $\cos \beta \cos \alpha$ \\
\hline
\end{tabular}


This transition table from a moving to a fixed coordinate system allows you to determine the projections of the forces acting on the chassis dynamometer on the part steerable wheel of a vehicle, taking into account his installation angle.

Conclusion. The result of this research is the table of transition between moving and immobile reference systems. This table enables to determine the projection of forces that arise when the steerable wheel of a vehicle is interacting to the supporting surface by changing its installation angles relative to the vehicle frame.

\section{References}

1. Хачатуров, А.А. (Ред.). (1976). Динамика системь «дорога - иина - автомобиль - водитель». Москва: Машиностроение.

2. Gillespie, T.D. (1997). Fundamentals of Vehicle Dynamics. SAE International

3. Великанов, Д.П. (Ред.). (1977). Автомобильные транспортные средства. Москва: Транспорт.

4. Гришкевич, А.И. (1968). Автомобили: теория.

Минск: Выша школа.

5. Wong, J.Y. (2008). Theory of Ground Vehicles. NYSE: John Wiley \& Sons Inc.

6. Taghavifar, H. \& Mardani, A. (2017). Off-road Vehicle Dynamics. Springer International Publishing

7. Сирота, B.I. (2005). Основи конструкиії автомобілів. Київ: Арістей.

8. Лудченко, О.А. (2003). Технічне обслуговування $i$ ремонт автомобілів. Київ: Знання-Прес.

9. Заикин, Г.М. (1960). Стенд для проверки схождения колес. Автомобильный транспорт, 7, 26-27.

10. Othman, N.A. \& Daniyal, H. (2015). Investigation on Chassis Dynamometer with Capability to Test Regenerative Braking Function. International Journal of Power Electronics and Drive System (IJPEDS), 6(3), 657-664. http://umpir.ump.edu.my/id/eprint/11368.

11. Sayers, M.W. \& Han, D. (1996). A Generic Multibody Vehicle Model for Simulating Handling and Braking. Vehicle System Dynamics, 25(1), 599-613.

doi:10.1080/00423119608969223.

12. MacAdam, C. (1988). Development of Driver-Vehicle Steering Interaction Models for Dynamic Analysis. University of Michigan Transportation Research Institute. https://apps.dtic.mil/dtic/tr/fulltext/u2/a208244.pdf.

13. Hong, C.W. \& Shio, T.W. (1996). Fuzzy control strategy design for an autopilot on automobile chassis dynamometer test stands. Mechatronics, 6(5), 537-555. doi:10.1016/0957-4158(96)00010-4

14. Лурье, А.И. (1961). Аналитическая механика. Москва, Техиздат. 